\title{
Happiness in Hard Times: Does Religion Buffer the Negative Effect of Unemployment on Happiness?
}

\author{
Orestes P. Hastings \\ Colorado State University \\ pat.hastings@colostate.edu \\ Kassandra K. Roeser \\ Stanford University
}

Published as:

Hastings, Orestes P. and Kassandra K. Roeser. 2020. "Happiness in Hard Times: Does Religion Buffer the Negative Effect of Unemployment on Happiness?” Social Forces 99(2):447-473.

https://doi.org/10.1093/sf/soaa018

\begin{abstract}
Two well-known findings are that the religious are happier than the non-religious, and people are less happy when they lose their job. We investigate a link between these by asking whether religion buffers against the negative effect of unemployment on happiness. Although theorized or implicitly assumed in many studies, empirical demonstrations of a causal, moderating effect of religion have been infrequent and often not strong methodologically. We conduct individuallevel fixed effects models to test for the buffering effect in the U.S. context using recent panel data from the 2006-2014 General Social Surveys (GSS). Religious service attendance, belief in life after death, and trying to carry one's religious beliefs over into other dealings in life all substantially buffered the effect of unemployment on happiness. Praying daily, believing God exists, identifying as a religious person, and having a religious affiliation did not. We discuss these results in the context of prior work and existing theory. To further support a causal interpretation of these findings, we also conduct a secondary analysis showing that unemployment does not appear to increase or decrease religiousness. This paper makes an important sociological contribution to the growing field of happiness research and to our understanding of how religion matters to people during hard times.
\end{abstract}




\section{Introduction}

Happiness, elusive as it may seem, is among the most essential measures of human flourishing. People spend lives pursuing it, and scholars across multiple disciplines research its many causes and consequences (for reviews, see Argyle 2013; Easterlin 2003; Frey and Stutzer 2002). This paper focuses on two determinants of happiness at the core of human life: work and religion.

Two well-known research findings are that, in general, the religious are happier than the non-religious (Ellison 1991; Ellison, Gay, and Glass 1989; Ferriss 2002; Greene and Yoon 2004; Hout and Greeley 2012; Hout and Hastings 2014; Lim and Putnam 2010; Myers 2008; VanderWeele 2017b), and people are less happy after they lose a job (Clark and Oswald 1994; Darity and Goldsmith 1996; Di Tella, MacCulloch, and Oswald 2001; Korpi 1997; McKee-Ryan et al. 2005). We investigate the link between these by asking whether religion buffers against the negative effect of unemployment on happiness. Although theorized or implicitly assumed in many studies (Bradshaw and Ellison 2010; Ellison 1991; Ellison et al. 1989; Ellison and George 1994; Krause 2002; Lechner et al. 2013; Lechner and Leopold 2015; Pargament 1997, 2010; Schieman et al. 2006; Smith, McCullough, and Poll 2003; Strawbridge et al. 1998), empirical demonstrations of a moderating effect of religion have been infrequent and often not based on methodologically strong research designs.

After describing previous theoretical and empirical work on religion, unemployment, and happiness, we conduct a rigorous test of its potential buffering effect in the U.S. context using recent panel data from the 2006-2014 General Social Surveys (GSS). Panel data allows us to gain some leverage on causality by estimating fixed effects models that better account for unobserved factors that may be confounded with the relationship of interest (Allison 2009; Morgan and Winship 2014; Vaisey and Miles 2017). We further demonstrate the need for panel data to account for selection bias into unemployment by showing that unhappy, employed people are more likely become unemployed in the future, and we estimate a baseline causal effect of unemployment on happiness - becoming unemployed leads to an average decline of 0.23 standard deviation's (SD) in happiness.

Next, the core of our analysis uses fixed effects models to test whether seven different measures of religion - spanning dimensions of religious community, beliefs, practices, and identity - moderate the effect of unemployment on happiness. We find evidence that religious service attendance, belief in life after death, and trying to carry one's religious beliefs over into 
other dealings in life all substantially buffer the effect of unemployment on happiness. However, we do not find any buffering effect from praying daily, believing God exists, identifying as a religious person, or having a religious affiliation.

We discuss these results and their implications in the context of prior work and existing theory. To further support a causal interpretation of our main findings, we also conduct a secondary analysis showing that unemployment does not increase or decrease religiousness. Finally, we conclude by discussing the limitations and scope conditions for this work, and outlining promising directions for future research. Although there is much more to be done, the results of this paper make an important sociological contribution to the growing field of the “science of happiness" (Diener 2000; Frey and Stutzer 2002; Kroll 2014) and to our understanding of how religion matters to people in hard times.

\section{Happiness and Unemployment}

Happiness is broadly understood to be an important dimension of quality of life and human flourishing (Argyle 2013; VanderWeele 2017a). Happiness itself is multi-dimensionalcapturing both instant evaluations by people of the events that occur in their lives (e.g. people report greater happiness when relaxing with friends or having sex, and less happiness when driving in traffic or talking to their bosses, see Krueger and Schkade 2008) and longer-term assessments, judgements, and comparisons (e.g., Easterlin 2003; Fischer 2008; Smith, Diener, and Wedell 1989). Fortunately, this latter part is relatively durable (Crooker and Near 1998; Frey and Stutzer 2002) and does well in measures of test-retest reliability (Hout and Hastings 2016; Krueger and Schkade 2008), making self-reported happiness something that can be quantified and systematically analyzed in relation to other "durable" factors. ${ }^{1}$

Numerous studies have found a strong negative relationship between unemployment and happiness (Clark and Oswald 1994; Darity and Goldsmith 1996; Di Tella et al. 2001; Korpi 1997; McKee-Ryan et al. 2005). Longitudinal-data can help determine the direction of causality, and there is evidence that the effect goes both ways: people become less happy when they become unemployed, but unhappy people are also more likely to become unemployed and have a harder time finding new work (Frey and Stutzer 2002).

There are multiple ways unemployment could reduce happiness. Some effects are likely due to the lost income, as both real and relative income are associated with happiness to some 
extent (Alderson and Katz-Gerro 2016; Easterlin 2003; Fischer 2008; Kahneman and Deaton 2010). Yet for a large U.S. sample, Fischer (2008) found no significant differences in happiness between those working part-time vs full-time vs those not in the labor force at all (e.g. retirees, stay-at-home parents, students). In other words, the unemployed are especially unhappy, which may be the result of economic distress arising from abrupt changes to income level (Latsou and Geitona 2018).

At the same time, unemployment may reduce social contact (e.g., with co-workers) and opportunities that can be important for happiness (Hiswåls et al. 2017). Further, unemployment may result in loss of self-esteem, sense of mastery, and meaning and purpose among former breadwinners (Goldsmith, Veum, and Darity 1996), and may increase anxiety, decrease morale, and heighten experiences of social stigma. Finally, unemployment presents individuals with the difficult and uncomfortable challenges of locating new employment (Hiswåls et al. 2017).

\section{Happiness and Religion}

Scholars have frequently found a link between happiness and religion both at the aggregate and individual levels (for examples, see Ellison 1991; Ellison et al. 1989; Ferriss 2002; Greene and Yoon 2004; Hout and Greeley 2012; Hout and Hastings 2014; Lim and Putnam 2010; Myers 2008; VanderWeele 2017b; but for exceptions, see Mochon, Norton, and Ariely 2011; OkuliczKozaryn 2010) . However, there is substantial debate over how (and even if) religion actually might influence happiness.

One explanation focuses on the personal networks and social support that frequently arise through religious communities, where involvement is typically measured by frequency of religious service attendance (e.g., Krause 2008; Lim and Putnam 2010; VanderWeele 2017b). Specifically, religious service attendance has been shown to correlate with larger friendship networks and a sense of feeling cared for by other parishioners (Ellison and George 1994; Lim and Putnam 2010). In turn, this may result in deeper social connections and strong positive emotions (Bradley 1995). Religious service attendance has also been found to be associated with less anxiety and greater tranquility (Ellison, Burdette, and Hill 2009). While one explanation would be that those who participate in religious communities are happier because they have larger social networks, studies have found that the link between religious involvement and happiness endures even after controlling for measures such as the frequency of social activities 
and the size of one's friendship network (Ellison et al. 1989; Greeley and Hout 2008).

Rather, there appears to be a distinction between religious and secular social resources. That is, religious social networks appear to have distinct qualities - tied either to the beliefs or the rituals of these communities - differentiating them from other types of social networks (Ellison and George 1994; Krause and Wulff 2005). But research has not found that specific religions or denominations seem to matter more, despite obvious doctrinal and practice differences between them (Hout and Greeley 2012; Lim and Putnam 2010).

A second explanation focuses on beliefs and non-organizational practices of religion that may increase happiness (Ellison 1991; Greeley and Hout 2008; Krause 2008). For example, religious faith enhances well-being by offering a comprehensive framework for the interpretation of world events, which provides existential certainty, and thus a sense of meaning and purpose in life in an unpredictable world (Emmons, Cheung, and Tehrani 1998; Inglehart 2010). Moreover, strong religious faith and personal religious experiences can improve well-being by bolstering self-esteem and self-efficacy (Ellison 1991).

Additionally, believing in life after death has been shown to be inversely related to anxiety and positively associated with tranquility (Ellison et al. 2009). Similarly, belief in life after death has been found to be related to better mental health outcomes, even after controlling for stress and social support, in turn suggesting that religious beliefs in particular may be especially beneficial (Flannelly et al. 2006).

A third explanation interrogates the role of religious identity in psychological well-being (Hackney and Sanders 2003). Individuals who identify as religious or with the same religious affiliation may vary substantially in their beliefs and practices (and, vice-versa, similar beliefs and practices can be observed across multiple religious affiliations), but this identity itself may be meaningful and important. In one study, people who identified as religious - measured by how religious they considered themselves and how much they sought to carry those beliefs into everyday life - reported greater levels of physical health and happiness as compared to those who do not identify with any religion-even after controlling for financial status, social support, and family status - suggesting stronger religious identity may allow individuals to use their religion to reframe challenging situations and enable them to construct meaning about achieving personal spiritual growth or taking part in a divine plan (Green and Elliott 2010).

These explanations need not be exclusive: individuals may find happiness benefits from 
their religious community, the strength of their own religious identity, and the particular set of beliefs they hold. Moreover, some benefits may rely on combinations of these things. For example, the benefit of religious beliefs for happiness may not be accessible unless accompanied by participation in a religious community (Hout and Greeley 2012).

Of course, some question whether the observed relationships should be interpreted as evidence of causal pathways at all. Cross-sectional data, in particular, can suffer from selfselection (e.g., happy people may take up religion, and people who find happiness in religion might be more likely to continue to participate in it) or unobserved differences between the religious and non-religious (e.g., an underlying characteristic that increases both religiousness and happiness) (Regnerus and Smith 2005). One counterfactual analysis using propensity score weighting found evidence of positive selection - those who have a religion are the ones most likely to benefit from religion's positive effects (Hout and Greely 2012). If the "untreated" nonreligious people were "treated" they would probably not become as happy as the religious, and while there is likely a causal effect of religion on happiness, it is not nearly as large as would appear from unadjusted differences. However, a two-wave panel study to control for baseline differences also found a significant relationship between frequency of religious service attendance and life satisfaction (Lim and Putnam 2010). Finally, a time-diary survey found people reported the highest level of positive emotions when they were involved in religious activities (Krueger et al. 2009). While it is possible people choose to do religious things because it makes them happy, these findings suggest that it is not merely that happy people also happen to do religious things.

\section{Religion as a Buffer?}

In addition to the direct effect of religion on happiness detailed above, previous research also suggests an additional reason religion may increase happiness: in hard times, religion buffers the negative impact on happiness. ${ }^{2}$ As with the direct effect, this buffering effect could occur through each of the major dimensions of religion described above: religious community, beliefs, practices, and identity.

\section{Religious community}

Participation in a religious community that provides social support may be particularly valuable 
during spells of unemployment. Social support found in the organizational aspects of religionfrequently operationalized as religious service attendance — provides avenues for individuals experiencing detrimental life conditions to ask for and receive advice and assistance (Bradshaw and Ellison 2010; Krause 2002; Lechner and Leopold 2015). Congregations are home to multiple forms of informal support, and active congregants report not only more social ties but more positive evaluations of the supportive quality of those relationships (Bradley 1995; Ellison and George 1994).

Lechner and Leopold (2015) examined whether religious attendance the negative impact of unemployment on life satisfaction in Germany. Utilizing four-waves of panel data, they found that religious attendance (especially weekly or more) buffered the negative effect of unemployment on life satisfaction. Religious attendance not only reduced the size of the initial fall in happiness due to unemployment, but those who attended more regularly experienced some recovery in happiness even during pro-longed unemployment.

\section{Religious beliefs and non-organizational practices}

Buffering could also be the result of particular beliefs and non-organizational practices that, for example, may allow individuals to feel closer to the divine, reinterpret difficult life events in terms of a grand divine plan, to find comfort and reassurance of God's love and care, or to let go of fear and hurt (e.g., Krause 2005; Pargament 1997, 2010; Pargament et al. 1998; Schieman et al. 2006). Specifically, religious coping may help explain the link between religiosity and psychological well-being. Religious individuals sometimes cope by carrying their religious beliefs into other dealings in their lives and make sense of the world around them (Pargament 1997). One study in the U.K. found optimistic religious coping strategies to be correlated with higher self-reported happiness (Lewis, Maltby, and Day 2005). Another study found that increased prayer frequency was associated with lower rates of depressive symptoms and greater self-esteem, and, in turn, suggested personal prayer frequency is more central to psychological well-being than general orientation towards religion (Maltby, Lewis, and Day 1999). Finally, Ellison et al. (2009) found that both belief in an afterlife and frequency of prayer buffered the adverse effects of poor health and financial decline on anxiety. 


\section{Religious identity}

One's religious identity or religious affiliation could provide a buffering effect. To some extent, one's self-identity may provide the framework for individuals to understand "who they are" and how they should respond to hard life situations, regardless of particular practices or beliefs. For example, a study of 140 male Muslims in the U.K. also found evidence that a scale of personal religious values buffered the impact of unemployment on psychological well-being (Shams and Jackson 1993).

Despite the well-established negative consequences of unemployment on happiness and the broad literature on how multiple dimensions of religion may plausibly buffer the effects of negative live events, relatively few studies have examined whether multiple dimensions of religion buffer the negative effects of unemployment, and thus provide limited insight into whether the effect vary. Bradshaw and Ellison (2010) examined the intersection between religion, financial hardship, and psychological distress, looking primarily into the possibility of religion - measured through prayer, meditation, attendance, and belief in an afterlife - acting as a buffer against the negative impacts of economic strain. Using a cross-sectional sample of the United States (the 1998 GSS), they found that low-income individuals reported higher levels of distress, but that these negative effects were attenuated by greater religious attendance, meditation, and belief in the afterlife (but not by prayer).

In one study of residents is one U.S. county (Alameda, California), Strawbridge et al. (1998) found that religiosity buffered effects of some stressors on depression but exacerbated others. Both non-organizational religiosity (prayer and importance of religious beliefs) as well as organizational religiosity (religious attendance) buffered depressive effects for non-family stressors, such as financial problems. By contrast, non-organizational religiosity was found to exacerbate depressive symptoms related to one's relationship with their children. Additionally, organizational religiosity was correlated with exacerbating depressive associations with family stressors, such as marital problems. In fact, this aligns with some scholarship suggesting religion could have a negative moderating effect: harmful — as well as helpful—forms of religious coping have been identified, and the harmful forms (e.g., discontentment or anger with God, congregational leaders, or avoiding difficulties through religious activities) correlate with worse mental health, poorer resolution of negative life events, and higher levels of depressive symptoms (Pargament 1997; Smith et al. 2003). 
Finally, in a cross-sectional study in Poland, both religious attendance and subjective religiosity (nonbeliever, having doubts in matters of faith, believer, or deep believer) buffered the impact of work-related demands on depressive symptoms, but not on life or work satisfaction (Lechner et al. 2013).

\section{The Current Study}

Taken together, a large body of literature suggests a theoretical relationship where religion (or some dimensions of it) should provide a buffer on the negative effects of unemployment. Yet prior empirical work is both limited in scope and has yielded mixed results. We advance this line of research by conducting a methodologically rigorous analysis on whether religion buffers the negative effects of unemployment.

We use a large panel dataset from the United States. While studies based on crosssectional data can control for any observed sociodemographic factors and well-known confounders, unobserved individual characteristics may still confound the relationships between religion, unemployment, and life satisfaction. In contrast, panel data allows us to make a stronger case for causal inference by employing fixed effects models where each person effectively serves as their own control for baseline differences between individuals (Allison 2009; Morgan and Winship 2014; Vaisey and Miles 2017).

The context of the United States is both an important aspect of this study's contribution and a notable scope condition. Our discussion of prior empirical work draws heavily on research based on samples in other contexts, and, as noted above, one of the most rigorous comparable studies was based on panel data in Germany (Lechner and Leopold 2015). But individuals in the U.S. are often differ in ways that lead to research based on U.S. respondents not generalizing to other - particularly non-western — contexts (and vice versa) (Henrich, Heine, and Norenzayan 2010). Specific to this study, the U.S. differs substantially from many other western countries in terms of having a weaker social safety net that might alter the consequences of unemployment (Brady, Finnigan, and Hübgen 2017) and a higher level of religiosity (Schnabel and Bock 2017). More broadly, different features of national contexts have been found to moderate the relationship between religion and happiness (Clark and Lelkes 2005; Diener, Tay, and Myers 2011; Eichhorn 2012; Lun and Bond 2013; Okulicz-Kozaryn 2010). Similarly, it is quite plausible that religion has a different moderating effect of unemployment on happiness in the 
United States than in other contexts (directions for future research are elaborated on in the Discussion).

Finally, we consider the effects of multiple dimensions of religion, which could influence happiness in different ways. As discussed above, religion could be a buffer through participation in a religious community, through particular personal beliefs and non-organizational practices, and/or through religious self-identity and affiliation. Our study employs measures of each which allows us to examine similarities and differences in the moderating effects of each.

\section{Data}

\section{General Social Survey}

We use all the available panel data from General Social Surveys (GSS), a nationally representative, face-to-face survey of non-institutionalized adults in the United States. ${ }^{3}$ Three sets of three-wave panels were administered (2006-2008-2010, 2008-2010-2012, 2010-2012-2014) with both initial response rates and re-interview rates greater than 70\% (Hout 2017). Because we are interested in the effects of unemployment, we restrict our sample to working age adults (ages 25-65) for whom the consequences of unemployment are likely serious. Furthermore, for those under 25 and over 65, transfers of resources from family members and government agencies may further obscure the effects of unemployment. The variables used in the analysis are described below, and descriptive statistics for all variables are in Appendix Table A1.

\section{Happiness}

Happiness is measured by asking respondents "Taken all together, how would you say things are these days - would you say that you are very happy, pretty happy, or not too happy?". Though simple, this item correlates with more elaborate scales (Andrews and Robinson 1991; Smith 1979) and has been used extensively in happiness research (Hout and Greeley 2012). Of the respondents in our analysis, 12\% were "Not too happy", 61\% were "Pretty happy", 28\% were "Very happy."

We present results treating this measure as a continuous variable, which is consistent with much other work (e.g., Crooker and Near 1998; Easterlin 2003; Fischer 2008; Hout and Hastings 2014) and has been shown to have high reliability across the GSS panels (Hout and Hastings 2016). For interpretability, we standardize this measure so units are in standard deviations (SD). 
Figure 1 presents the average happiness (left y-axis) of our analysis sample for each year, ranging from $.05 \mathrm{SD}$ below to $.1 \mathrm{SD}$ above the overall mean (note our regression analysis is at the individual level, but the figure illustrates variation of time).

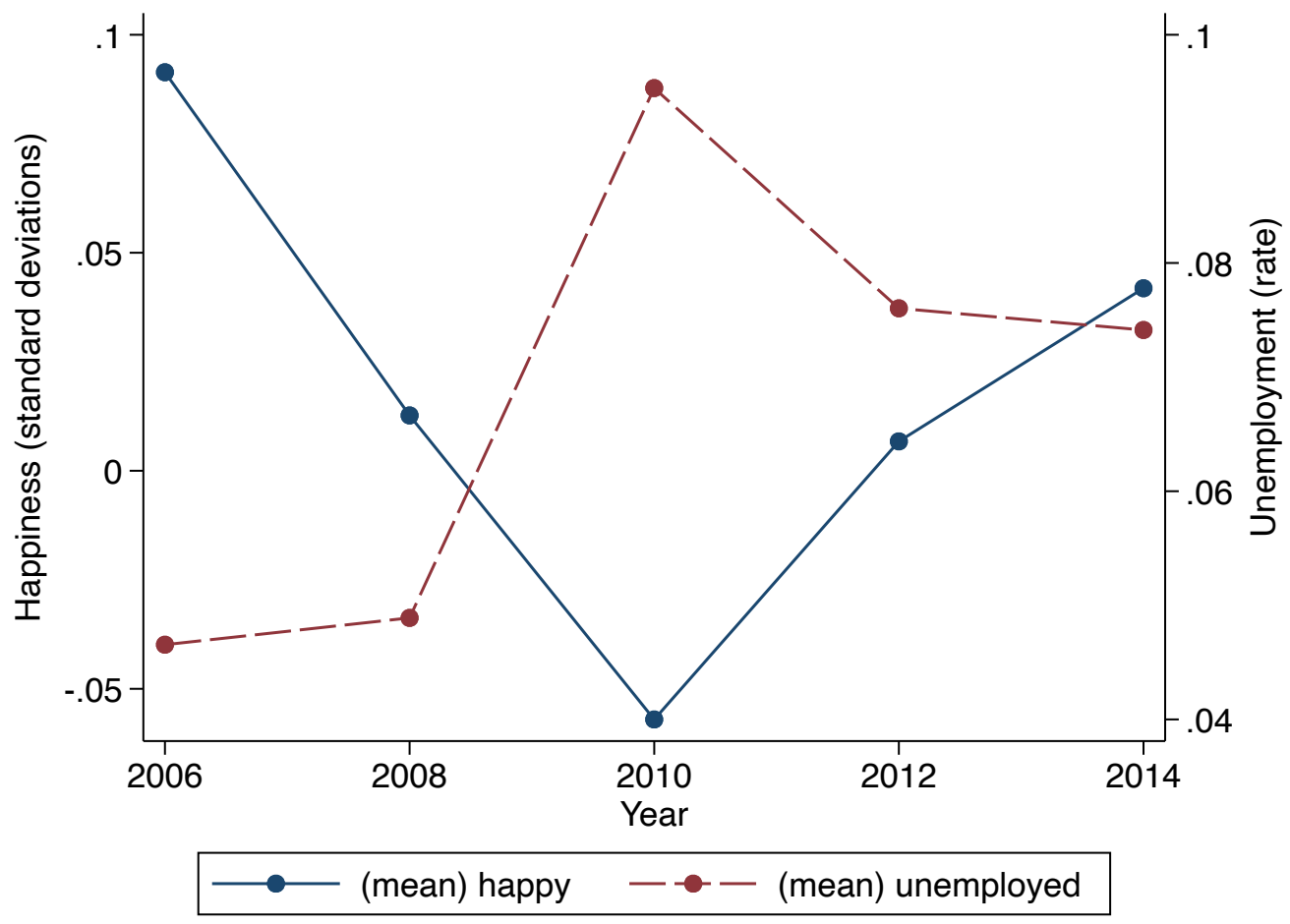

Figure 1: Happiness and unemployment by year, 2006-2014.

\section{Unemployment}

We create a binary measure of unemployed vs employed. We exclude respondents who are not in the labor force (including retired, keeping home, and/or students). We combine both part-time and full-time workers as employed and found no meaningful differences when separating the two.

During the early part of the period our study examines, the U.S. went through the "Great Recession", which provides a significant number of cases of respondents losing their job. This is reflected in Figure 1 which presented the unemployment rate (right y-axis) of our analysis sample, ranging from 4.6-9.8\%, which closely aligns with the official unemployment rates from the Bureau of Labor Statistics. The over-time patterns between unemployment and happiness are consistent with an inverse relationship. 


\section{Religion}

Our choice of religion measures is driven by both theoretical and pragmatic reasons. We aspired to capture measures of religious community, personal religious beliefs and non-organizational practices, and religious identity and affiliation - given that each has some theoretical basis or precedent for being a moderator. The GSS provides seven such variables which are widely-used in religious research (another variable has very different meanings to adherents of different religious traditions — beliefs about the Bible — and so is not included). Each religion variable, the corresponding GSS question, its coding, and basic descriptives are presented in Table 1.

Table 1: Religion Variables

\begin{tabular}{|c|c|c|c|c|}
\hline Variable & GSS Questions & Coding & $\begin{array}{c}\text { Mean/ } \\
\text { Proportion }\end{array}$ & $\begin{array}{l}\text { Standard } \\
\text { Deviation }\end{array}$ \\
\hline $\begin{array}{l}\text { Pray daily } \\
\text { or more }\end{array}$ & "About how often do you pray?" & $\begin{array}{l}1=\text { daily or more often } \\
0=\text { less than daily }\end{array}$ & 0.53 & \\
\hline $\begin{array}{l}\text { Believe } \\
\text { God exists }\end{array}$ & $\begin{array}{l}\text { "Which of the statements comes } \\
\text { closest to expressing what you } \\
\text { believe about God: (1) I don't } \\
\text { believe in God, (2) I don't know } \\
\text { whether there is a God and I don't } \\
\text { believe there is any way to find out } \\
\text { (3) I don't believe in a personal } \\
\text { God, but do believe in a Higher } \\
\text { Power of some kind (4) I find } \\
\text { myself believing in God some of } \\
\text { the time, but not at others (5) } \\
\text { While I have doubts, I feel that I } \\
\text { do believe in God (6) I know God } \\
\text { really exists and I have no doubts } \\
\text { about it }\end{array}$ & $\begin{array}{l}1=\text { "I know God really exists" } \\
0=\text { all other responses }\end{array}$ & 0.57 & \\
\hline $\begin{array}{l}\text { Believe in } \\
\text { life after } \\
\text { death }\end{array}$ & $\begin{array}{l}\text { "Do you believe there is a life after } \\
\text { death?" }\end{array}$ & $\begin{array}{l}1=\text { yes } \\
0=\text { "no" and "don't know" }\end{array}$ & 0.73 & \\
\hline $\begin{array}{l}\text { Religious } \\
\text { person }\end{array}$ & $\begin{array}{l}\text { To what extent do you consider } \\
\text { yourself a religious person? Are }\end{array}$ & $\begin{array}{l}1=\text { Very religious } \\
.66=\text { Moderately religious }\end{array}$ & 0.51 & 0.32 \\
\hline
\end{tabular}




\begin{tabular}{|c|c|c|c|c|}
\hline & $\begin{array}{l}\text { you very religious, moderately } \\
\text { religious, slightly religious, or not } \\
\text { religious at all? }\end{array}$ & $\begin{array}{l}.33=\text { Slightly religious } \\
0=\text { Not religious at all }\end{array}$ & & \\
\hline $\begin{array}{l}\text { Carry } \\
\text { religious } \\
\text { beliefs into } \\
\text { rest of life }\end{array}$ & $\begin{array}{l}\text { Please tell me whether you } \\
\text { strongly agree, agree, disagree, or } \\
\text { strongly disagree with the } \\
\text { following statement: I try hard to } \\
\text { carry my religious beliefs over into } \\
\text { all my other dealings in life? }\end{array}$ & $\begin{array}{l}1=\text { Strongly agree } \\
0.66=\text { Agree } \\
.33=\text { Disagree } \\
0=\text { Strongly disagree }\end{array}$ & 0.60 & 0.32 \\
\hline
\end{tabular}

a. See Presser and Chaves (2007) for background about the coding of probability of religious service attendance.

b. This question was discontinued after 2010. So, all survey respondents were asked the question in their first year (when religion is measured for the main models), but not in every year.

We measure religious community through religious attendance by converting each response category (from "never" to "several times a week") into a probability of attending on any given week using a transformation described in Table 1 . We also examined the bivariate relationship between happiness and attendance and observed a marked increase in happiness when attendance was once a month or more (in a t-test, those attended monthly or more were .22 SD happier, $\mathrm{p}<.001)$. An analysis using a measure of attending religious services monthly or more yielded similar results (see Appendix Table A11).

Our measures of private religious practices and beliefs are binary measures of whether one prays at least daily (58\% do), knowing that God exists $(61 \%)$, and believing in life after death (72\%). Although prayer and belief in God are measured with scales in the GSS, these measures are skewed with the majority of respondents reporting praying often and believing in God (see Figures A1 and A2 of the Appendix). So, we use binary measures, but models using the full scales are in the Appendix. Belief in the afterlife was a yes/no question, but many respondents reported "don't know", which the GSS defaults to missing. However, "don't know" in this case seems substantively important, and we include those respondents in the same category as those who do not believe in life after death.

We measure religious identity and affiliation: first, we measure whether an individual has a religious affiliation $(82 \%$ do), and then we measure the intensity of their religious identity on a scale of how religious someone considers themselves. Finally, we analyze the moderating effect of how much a respondent agrees with, "I try hard to carry my religious beliefs over into all my other dealings in life." This measure has been used to operationalize religious identity, but it also intersects with religious beliefs and practices and may be seen as a combination of these dimensions (Hill and Pargament 2008; King and Hunt 1975; Koenig and Büssing 2010). ${ }^{4}$ 


\section{Controls}

We control for several additional factors that might moderate the effect of unemployment on happiness and thus confound the potential moderating effect of religion. We control for age, sex (Knabe and Rätzel 2011), years of education, race/ethnicity (non-Hispanic white, non-Hispanic black, Hispanic, and other) (Schieman et al. 2006), marital status (married, divorced, widowed, separated, and never married) (Easterlin 2003), and number of children (Clark et al. 2008). Only 26 observations were dropped due to missing data in the control variables.

\section{Method}

We establish the basis for a panel analysis by first estimating a "naïve" regression model of whether or not unhappy people are more likely to be unemployed. That is, we regress unemployment on happiness, including year fixed effects and clustering standard errors at the individual level. Second, we regress unemployment on happiness in the prior year, conditional on being employed in the previous year. This shows whether employed but unhappy people are more likely to become unemployed in the future, which could indicate selection in unemployment (perhaps due to, most obviously, being unhappy with one's job). Panel data can help address this potential source of bias. Third, we regress happiness on unemployment (simply swapping $y$ and $x$ from the first model). This estimates the "effect" of unemployment on happiness, ignoring selection issues. Fourth, we conduct an individual-level fixed effects regression of happiness on unemployment. Formally, for respondent $i$ in survey wave $t$, the model can be written as

$$
\text { Happiness }_{i t}=\beta_{0}+\beta_{1} \text { Unemployed }_{i t}+\text { year }_{t}+\alpha_{i}+u_{i t}
$$

where $y e a r_{t}$ indicates year fixed effects, $\alpha_{i}$ indicates individual fixed effects, and $u_{i t}$ is the error term. The inclusion of individual-level fixed effects means that estimated effect of unemployment is based on the changes within each respondent before and after becoming unemployed, and all time-constant characteristics of each individual, measure or unmeasured, are accounted for. If unemployment has a negative causal effect on happiness, we expect a negative $\beta_{1}$. Without this, there would be no causal effect of unemployment for religion to moderate.

We then move to the heart of our analysis, examining if religion is a buffer to the 
negative effect of unemployment. We test for moderation with an interaction term between unemployment and each religion variable. However, religion itself can change over time (potentially even due to unemployment, something we address below). To avoid confounding the effects of changes in unemployment status with the effect of changes in religion, we use a timeconstant measure of religion, measured in the initial wave, which thus precedes any spells of unemployment. Because we are interested in the causal effect of becoming unemployed, we exclude wave 2 and wave 3 observations where a respondent is employed after being previously unemployed - otherwise we would also be estimating the effect of gaining a job on happiness, which, while interesting, is beyond the scope of this paper (and most literature). Formally, we write this as:

$$
\begin{gathered}
\text { Happiness }_{i t}=\beta_{0}+\beta_{1} \text { Unemployed }_{i t}+\beta_{2} \text { Unemployed }_{i t} \\
+ \text { year }_{t}+\alpha_{i}+\text { Religiousness }_{i}
\end{gathered}
$$

where Religion ${ }_{i}$ is one of our measures of being religious. Because this measure is timeinvariant, there is no "main effect" of religion to estimate in our main model. The focus of our test is $\beta_{2}$. A positive term suggests a causal moderating effect of religion.

However, because of the inclusion of the interaction term, our fixed effects model may still include time-invariant factors that may be associated with religion and also moderate the effect of unemployment and happiness (for a parallel example examining the moderating effect of income inequality on social class and high-school graduation, see Kearney and Levine 2016). For example, religion could stand in as a proxy for age or education (or anything else), and while the "main effect" of these confounders is already accounted for in the fixed effects, the moderating effect still needs to be controlled for. We do this by including interaction terms between unemployment and each of our controls. Again, we measure each of the controls at their initial (wave 1) values to ensure they cannot be affected by future unemployment. Formally, we write this as:

$$
\begin{gathered}
\text { Happiness }_{i t}=\beta_{0}+\beta_{1} \text { Unemployed }_{i t}+\beta_{2} \text { Unemployed }_{i t} \times \text { Religiousness }_{i} \\
+\sum_{c} \beta_{c} \text { Unemployed }_{i t} \times \text { Controls }_{i c}+\text { year }_{t}+\alpha_{i}+u_{i t}
\end{gathered}
$$


where $c$ denotes each one of the control variables listed above. Again, our focus is on $\beta_{2}$.

Finally, we add a model with all of the interactions between unemployment and each religion measure. This estimates the moderating effect of each measure of religion, net of the moderating effect of every other measure. Formally, we write this as:

$$
\begin{aligned}
\text { Happiness }_{i t} & =\beta_{0}+\beta_{1} \text { Unemployed }_{i t}+\sum_{r} \beta_{r} \text { Unemployed }_{i t} \times \text { Religiousness }_{i r} \\
& +\sum_{c} \beta_{c} \text { Unemployed }_{i t} \times \text { Controls }_{i c}+\text { year }_{t}+\alpha_{i}+u_{i t}
\end{aligned}
$$

where $r$ denotes each one of the the religion measures listed in Tabel 1. Our focus in on $\beta_{r}$.

We supplement the main analysis with a test of whether unemployment affects religiousness. If religion helps people in difficult times, they may be more likely to turn towards it when unemployed; however, if people blame a higher power for their problems, unemployment might cause them to turn to other sources for comfort (Farias et al. 2013; Pargament 2010; Pargament et al. 1998). We examine this by estimating a fixed effects model of religiousness on unemployment

$$
\text { Religiousness }_{i t}=\beta_{0}+\beta_{1} \text { Unemployed }_{i t}+\text { year }_{t}+\alpha_{i}+\mu_{i t}
$$

and focusing on the estimate of $\beta_{1}$. If unemployment has a causal effect on religiousness, this puts into the doubt the utility of using a time-invariant measure of religiousness, whereas a null result would support our earlier decision.

\section{Results}

\section{Baseline results}

Table 2 presents the baseline results, which put the panel models into context. Consistent with prior research, Model 1 shows a negative and significant effect of unemployment on happiness: 1 SD lower in happiness is associated with being 2.6 percentage points higher in the likelihood of being unemployed. Are less happy people more likely to become unemployed? Indeed, Model 2 shows that, among the currently employed, being 1 SD lower in happiness is associated with being 1.9 percentage points higher in the likelihood of being unemployed in the next wave. The 
indicates selection into unemployment, which our panel models help address.

Table 2: Results of baseline regression models

\begin{tabular}{|c|c|c|c|c|}
\hline & (1) & $(2)$ & (3) & (4) \\
\hline happy & $\begin{array}{c}-0.026 * * * \\
(0.0042)\end{array}$ & & & \\
\hline happy (lagged) & & $\begin{array}{c}-0.019 * * * \\
(0.0048)\end{array}$ & & \\
\hline unemployed & & & $\begin{array}{c}-0.56^{* * *} \\
(0.082)\end{array}$ & $\begin{array}{l}-0.23^{*} \\
(0.11)\end{array}$ \\
\hline Year fixed effects & Yes & Yes & Yes & Yes \\
\hline Constant & Yes & Yes & Yes & Yes \\
\hline$N$ (observations) & 6327 & 3708 & 6327 & 6327 \\
\hline $\begin{array}{l}\text { Dependent } \\
\text { variable }\end{array}$ & unemployed & unemployed & happy & happy \\
\hline Model Type & $\begin{array}{c}\text { OLS with } \\
\text { clustered s.e. }\end{array}$ & $\begin{array}{c}\text { OLS with } \\
\text { clustered s.e. }\end{array}$ & $\begin{array}{c}\text { OLS with } \\
\text { clustered s.e. }\end{array}$ & $\begin{array}{c}\text { Individual } \\
\text { Fixed Effects }\end{array}$ \\
\hline Model Notes & & $\begin{array}{l}\text { Only includes } \\
\text { respondents } \\
\text { employed in } \\
\text { previous wave }\end{array}$ & & \\
\hline
\end{tabular}

Standard errors in parentheses

${ }^{*} p<0.05,{ }^{* *} p<0.01,{ }^{* * *} p<0.001$

Model 3 regresses happiness on unemployment, providing a naïve estimate of the "effect" of unemployment: unemployed individuals are .56 SDs less happy than employed individuals. How much of this is causal? Model 4 presents the same estimate, but with the inclusion of individual fixed effects (Eq. 1). Based on this within-estimator, becoming unemployed leads to an average decline of 0.23 SDs in happiness - or about $40 \%$ of the estimate in Model 3. While smaller, this estimate is still substantial (e.g., under a normal distribution, 0.23 SD below the mean is about the $41^{\text {st }}$ percentile) and likely much closer to the true "causal effect."

\section{Main Results of Religious Buffer Test}

Having confirmed there is an unemployment effect to explain, we examine if religion is a 
buffer to the negative effect of unemployment by testing for moderation with the inclusion of an interaction term between unemployment and each religiousness variable in a fixed effects model. We first estimate the models without other moderating controls (Eq. 2), then with those controls (Eq. 3), and then with all religion moderators in the same model (Eq. 4). Table 3 shows the results for the first measure: probability of attendance (the full regression model is in Appendix Table A3).

Table 3: Fixed effects model of whether probability of religious service attendance moderates the effect of unemployment on happiness

\begin{tabular}{lccc}
\hline & $(1)$ & $(2)$ & $(3)$ \\
\hline Unemployed & $-0.40^{* *}$ & -1.05 & -0.92 \\
& $(0.11)$ & $(0.69)$ & $(0.65)$ \\
Unemployed x Probability of Attendance & $0.55^{+}$ & $0.58^{*}$ & $0.77^{* *}$ \\
& $(0.29)$ & $(0.26)$ & $(0.29)$
\end{tabular}

Unemployed x Carry relig beliefs into rest of life

Unemployed x Religious person

Unemployed x Pray daily or more

Unemployed x Believe God exists

Unemployed $x$ Believe in life after death

$0.45^{*}$

Unemployed x Religious affiliation

\begin{tabular}{lccc} 
Controls & No & Yes & Yes \\
Year fixed effects & Yes & Yes & Yes \\
& & & Yes \\
Constant & Yes & Yes & 6145 \\
$N$ (observations) & 6314 & 6314 & 2347 \\
\hline
\end{tabular}

Note: Controls are interaction terms between unemployment and age, sex, education, race/ethnicity, marital status, and number of children. Model 3 has a slightly smaller $\mathrm{N}$ due missing data on other religion measures besides attendance. The full models are in the Appendix. ${ }^{+} p<.1,{ }^{*} p<.05,{ }^{* *} p<.01$ 
The key coefficients are the interaction terms. In Model 1, the effect is positiveconsistent with a moderating effect-and marginally significant $(\mathrm{p}=.058)$. However, upon including other moderating controls for Model 2 , the magnitude of this effect increases slightly while the standard error decreases, yielding a conventionally statistically significant result $(\mathrm{p}<$ .05 ). The magnitude of this effect further increases and remains significant in Model 3, once adjusting for the moderating effect of other religion moderators. Based on Model 3, someone who attends church for $80 \%$ of the weeks in a year (42 weeks) would experience a $[.77 \times$ x (.8 $.3)]=0.39 \mathrm{SD}$ smaller decrease in happiness than someone who attends only $30 \%$ of the weeks in a year (16 weeks). This is substantial, as it is about $70 \%$ larger than the average effect of unemployment estimated from Model 4 of Table 2. We interpret this as support of a causal moderating effect. We also found substantively identical results using a dichotomous measure of attendance (monthly or more) in a supplemental model (Appendix Table A11).

For each additional religion measure, we substitute our measure of religion, both with and without the additional moderating controls in Eqs. 2 and 3. These models are in the Appendix (Tables A4-A10). For parsimony, we present the results visually in Figure 2, showing the coefficient of the interaction term between unemployment and religion in every model. The first column shows the interaction terms from the models without controls (Eq. 2), the second column shows the results from the models that include them (Eq. 3), and the third column shows the results from the model with all religion moderators (Eq. 4 and Model 3 of Table 3). In general, adding the controls has little effect on the magnitude of the key interaction term but slightly improves the precision by narrowing the confidence intervals. When adding all religion moderators, our estimates are largely similar, although the confidence intervals increase, likely from collinearity between the different religion measures.

The first row shows the probability of attendance, communicating the same results as in Table 3 . Each additional row shows the moderating effect of a different measure. Positive, statisticallysignificant coefficients are evidence of a buffering effect of religion. Prayer-our only available measure of a (often) private religious practice - presents no evidence of a buffering effect, nor did reporting that one believes God exists. We ran supplemental models using the full 6-item scale of prayer (never - several times a day) and the full 6-item beliefs about God (don't believe - known god exists) and found similar null results (Appendix Tables A12 and A13). However, believing in life after death showed strong evidence of a buffering effect. 


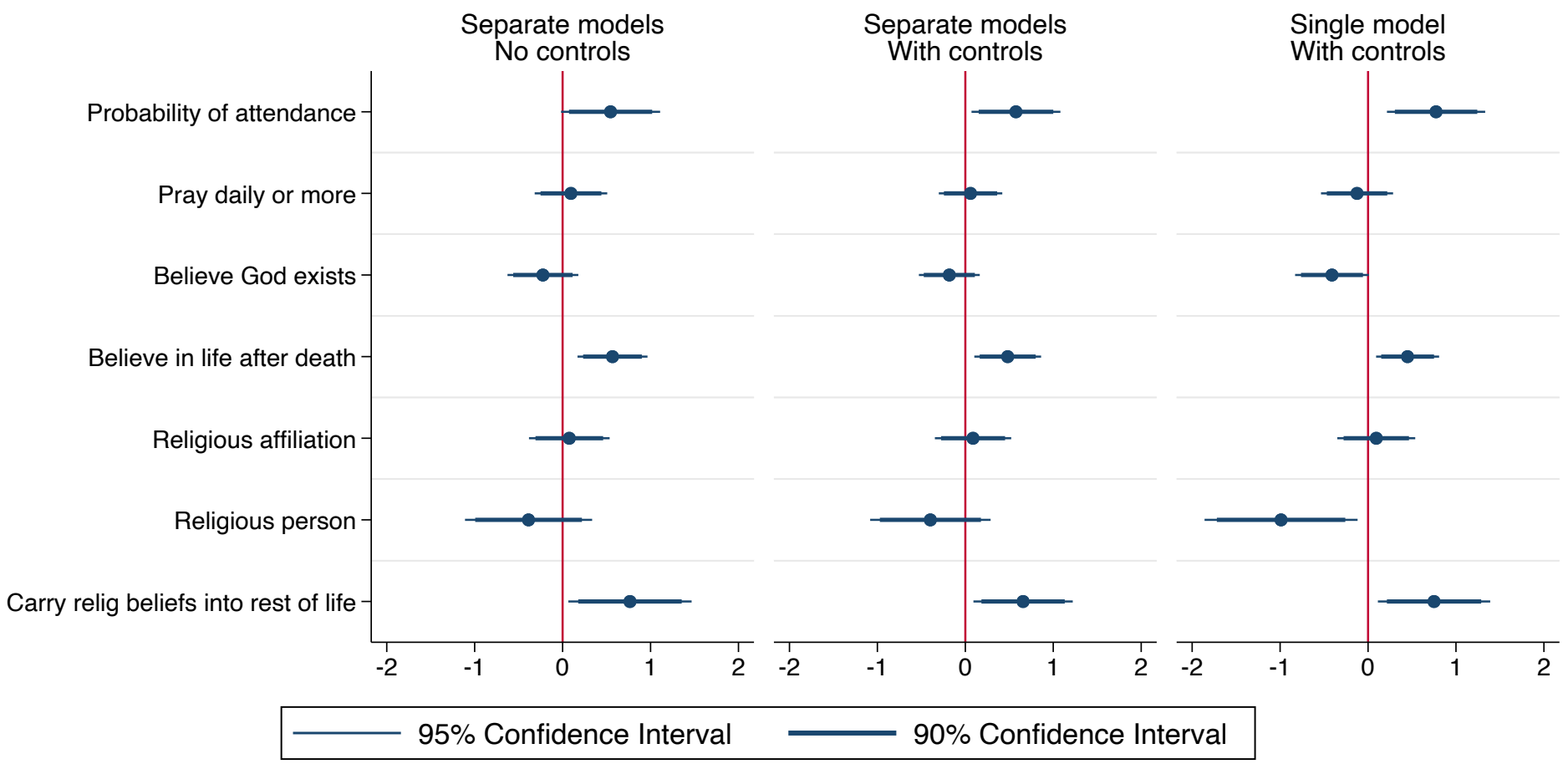

Figure 2: Coefficient plots of fixed effect models showing buffering of religion on the effect of unemployment on happiness.

Note: Each row corresponds to the coefficients of the interaction terms of that religiousness variable with unemployment. Positive and significant coefficients (i.e., confidence intervals that do not include zero) are evidence of a buffering effect.

Neither reporting having a religious affiliation nor being more religious has any positive buffering effect. In the full model, the effect of a religious affiliation is significantly negative ( $p$ $<.05$ ) - that is, net of all other moderating effects of religion, simply having a religious affiliation is associated with an even larger decline in happiness when becoming unemployed. Finally, agreement with the statement that one tries to carry their religious beliefs over into the rest of life does have a positive moderating effect in every model.

\section{Secondary Results of Effect of Unemployment on Religiousness}

We follow our main test of the buffering effect of religion with a secondary analysis of whether or not unemployment affects religiousness. If unemployment has a causal effect on religiousness (positive or negative), this weakens the practicality of using a time-invariant measure of 
religiousness as we do in the main results above.

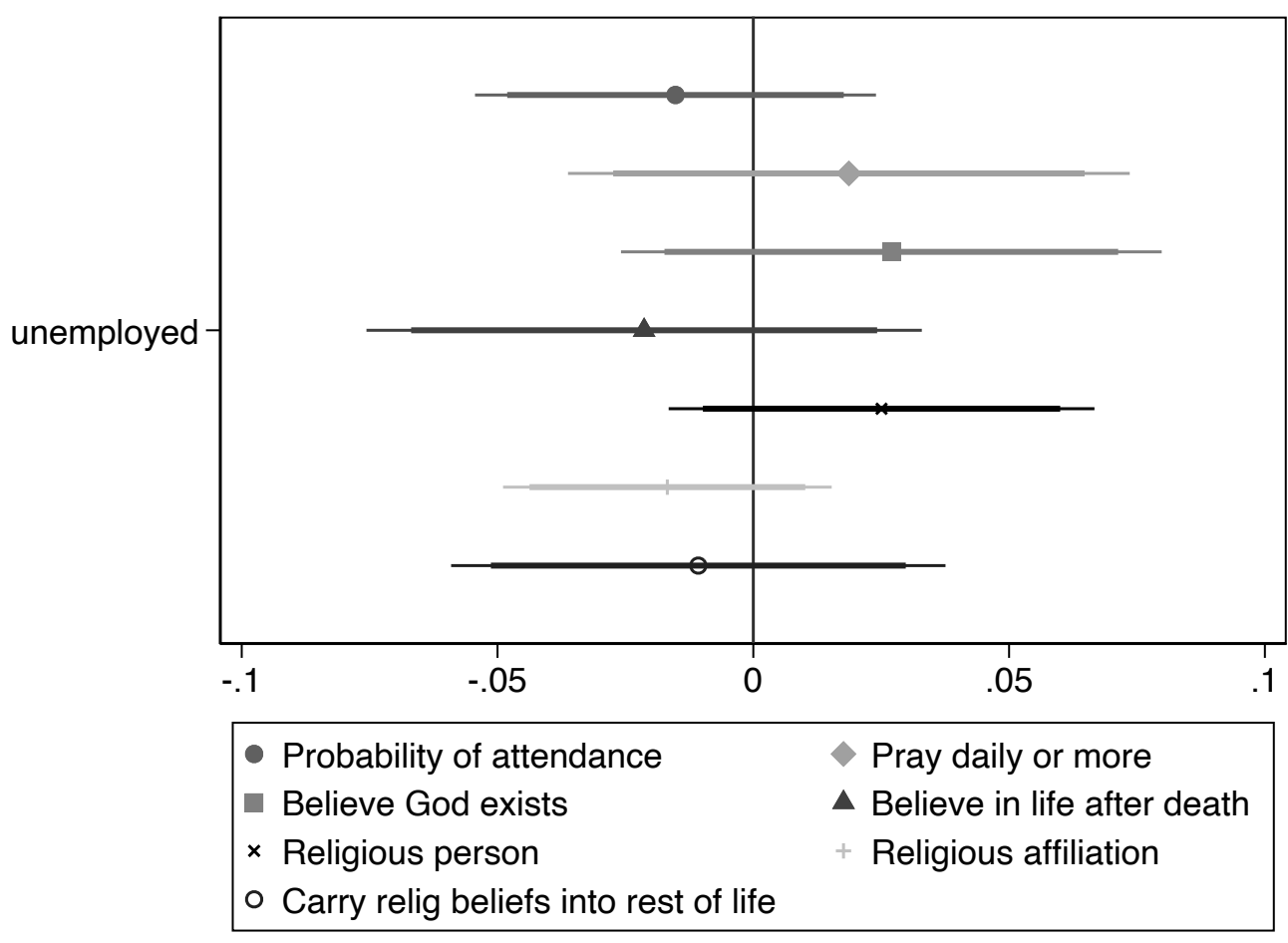

\section{Figure 3: Coefficient plots of fixed effects models showing effect of unemployment on religiousness.}

Note: Each coefficient comes from a separate model, corresponding to the estimate of the effect of unemployment for each measure of religiousness. Thick lines indicate the $90 \%$ confidence interval; thin lines indicate the $95 \%$ confidence interval.

We estimate fixed effects models using each time-varying measure of religiousness as our dependent variable (Eq. 4). The effect of unemployment is shown visually in Figure 3 (full results in Appendix Table A15). The confidence interval of every measure includes zero (i.e., none of the estimates are statistically significant at even the $p<.1$ level). Furthermore, the size of the estimates is not large - the largest point estimate is less than 0.03 , which is less than $3 \%$ of the range (all the religion measures range from $0-1) .{ }^{5}$ In short, there is no evidence that unemployment has any causal effect on any measure of religiousness, which supports our decision to estimate the models we do to test for a religious buffering effect. 


\section{Discussion and Conclusion}

Is religion a buffer against the negative effect of unemployment on happiness? Our conclusion: Yes, but with caveats.

In our analysis, we initially confirmed a longstanding relationship between happiness and unemployment. We showed important selection effects regarding who becomes unemployed that could lead to overestimating the effect of unemployment of happiness, but we address this with fixed-effects models and still find evidence of a negative causal effect of unemployment on happiness.

The center of our analysis tested whether seven different measures of religiousnessspanning dimensions of religious community, beliefs, practices, and identity-moderated the effect of unemployment on happiness. First, we find evidence that religious service attendance (although, this variable was only marginally significant before controlling for confounding moderating effects) buffers the effect of unemployment on happiness. As previous researchers have suggested, religious community may be particularly valuable during spells of unemployment, when individuals can receive support, advice, and assistance (Bradshaw and Ellison 2010; Krause 2002; Lechner and Leopold 2015). ${ }^{6}$

We found regular prayer did not have a buffering effect. While theory suggests prayer might help people cope with hard times (e.g., Maltby, Lewis, and Day 1999), Bradshaw and Ellison (2010) found a similar non-significant interaction between prayer and distress in their cross-sectional analysis. They speculated one explanation might be that being in causes people to pray more. Because our analysis uses panel data, we measure prayer prior to unemployment, but still no moderating effect is found. More work is needed to understand this null result.

Belief in the existence of God did not have a moderating effect. This may align with research suggesting that specific beliefs or feelings about God—such as his love and care or divine control - are what matters, rather than merely confidence in God's existence (e.g., Krause 2005; Pargament 1997, 2010; Pargament et al. 1998; Schieman et al. 2006). On the other hand, belief in life after death did matter, suggesting that perhaps this belief can help individuals put into perspective difficult situations in their current lives, including unemployment (Bradshaw and Ellison 2010).

We found no buffering effect for having a religious affiliation or the extent to which one identifies as a religious person. One explanation is that broad terms may not capture what matters 
about religion. Scholars have found wide variation in the frequency of religious attendance and practices across religious traditions (Jung 2014; Roof and McKinney 1987). Moreover, religious denominations differ in the promotion of social resources that can buffer against harmful effects of stress on mental health (Jung 2014) and shape distinct subcultures that may affect the link between religious attendance and happiness (Ellison 1991). Exploring variation in the moderating effects of religion across religions traditions and denominations may be fruitful line of inquiry (Clark and Lelkes 2005).

Finally, we found that trying to carry one's religious beliefs over into other dealings in life substantially buffers the effect of unemployment on happiness. Someone who intentionally tries to apply their religious beliefs - which are often intended to speak to life's most difficult situations - is best positioned to find utility from them. ${ }^{7}$ We conclude our analysis with secondary results showing that unemployment does not appear to increase or decrease religiousness.

Our findings are consistent with earlier work by Bradshaw and Ellison (2010) who found moderating effects of religious attendance and belief in the afterlife, but not of prayer. They partially support the findings of Ellison et al. (2009) who found buffering effects for belief in the afterlife (which we do) and for prayer (which we do not). Both of those studies focused on slightly different outcomes and hardship measures and used cross-sectional samples, and indeed both studies called for future work to use longitudinal data, which we are able to do in this paper. Our results also support the findings of the longitudinal German study of Lechner and Leopold (2015) that found a buffering effect of religious service attendance.

Contrary to suggestions that some dimensions of religiousness could have a harmful moderating effect (Pargament 1997; Strawbridge et al. 1998), we find little evidence of a negative moderating effect. One exception to this was that net of all other moderating effects of religion, having a religious affiliation is associated with a negative moderating effect. More broadly, the literature on negative effects of religion has centered on "spiritual struggles," which may not be well measured with the religion questions available in the GSS (Exline et al. 2014). As a result, the negative religious dimensions that have negative moderating effects may not be able to be observed with the available data.

Our paper comes with some important limitations in terms of the analysis and scope. First, from a data standpoint, we observe waves with two-year gaps. Some respondents might 
have lost their job last month while others 23 months ago, and duration of unemployment appears to affect happiness (Clark et al. 2008; Hahn et al. 2015) — a relationship itself that may be moderated by religion (Lechner and Leopold 2015). Furthermore, some respondents might lose and regain a job within a two-year period - variation that would be missed for this analysis. Retrospective detailed employment histories are collected in many studies and could be helpful here. Of course, retrospective happiness reports are unlikely to be reliable, and more frequent (but costly) waves of data collection would be ideal.

Second, despite the strength of panel data, the data are still observational and there are potential threats to a causal interpretation of our findings. The most likely potential confounder would be something — such as a personality type or a feature of an individual's upbringing or life history - that is associated to an individual's religion and also moderating the effects of unemployment on happiness, net of any moderating effects of the controls (sex, age, number of children, education, race/ethnicity, and marital status). It is also possible for a time varying factor - which is not controlled for through fixed effects - associated with religiousness and with changes to employment status and happiness to be a confounder. We confirmed our results were robust when controlling for changes in marital status and family size, but there could be others. The "ideal" research design to obtain the true causal estimate would require some form of random assignment, but it is impossible to randomly assign religion and difficult to randomly assign unemployment (or to find instruments that plausibly introduce enough randomness to both), so this is the best we think is possible with existing data.

Third, this research focuses on the U.S. context. The paper draws on prior empirical work based on samples in other contexts, including the U.K., Germany, and Poland. As noted, respondents in the U.S. are often quite unique (Henrich et al. 2010), and America differs substantially in terms its social safety net (Brady et al. 2017) — which might alter the consequences of unemployment — and levels of religiosity (Schnabel and Bock 2017). We agree with calls to do additional research in other, particularly non-western, contexts where the relationships between religion, unemployment, and happiness may differ (e.g., Eichhorn 2012).

Turning to a sub-national focus, it is possible that effects might vary across geographic contexts within the U.S. For example, studies have shown unemployment rates seem to moderate the consequence of unemployment (e.g., Oesch and Lipps 2012), and rates of religion participation affect pro-social behaviors such as volunteering, even for the non-religious (e.g., 
Lim and MacGregor 2012). Given that both unemployment rates and religiosity vary within the U.S. (e.g., by county, state, or region), so too might the buffering effect. The analysis in this paper - conducted on a nationally representative sample - can only estimate the average buffering effect. Conceivably, a direction for future research could be to estimate models with three-way or four-way interaction terms between unemployment, religion, the unemployment rate in a particular context, and the religiosity of a particular context to examine how the buffering effect of religion might vary (or not) across contexts.

More broadly, unemployment is only one case of difficult life events. Marital separation and divorce, physical and mental illness, and the death of family and friends are some other examples. While beyond the scope of this paper, future research should utilize a similar rigorous longitudinal research design to see if and how religion buffers these events. Given, for example, that many religious teachings and norms have something to say about divorce, religiousness may have a different moderating effect than for unemployment.

Relatedly, happiness is only one (albeit, large and important) dimension of human wellbeing and flourishing, which includes physical and mental health, social relationships, and meaning and purpose, among other things (VanderWeele 2017b, 2017a). Indeed, the background research presented at the front of this paper drew on studies examining life satisfaction, social well-being, stress, anxiety, and tranquility, among others. The outcome in this paper simply captures whatever people mean when they self-report their own happiness. More research can and should rigorously examine religion's role as a moderator of other relevant outcomes.

Another future direction for this work would be to better understand the relationship between religion, life satisfaction, and gaining a job. Of course, happiness improves when one finds a job, but some research suggests there is a "scarring effect" wherein happiness does not recover (or not quickly) to its pre-unemployment levels after finding a job (Knabe and Rätzel 2011). Furthermore, social networks — which could include those within a religious congregation - can be useful for getting a job and thus reducing the spell of unemployment (Granovetter 1973; Mouw 2003). Future research into how religion affects the job search process and how it may moderate the effect of obtaining a job could fruitful.

While there are many promising directions for this research going forward, our paper provides a new and more rigorous test of the oft-theorized relationship in which religion (or 
some dimensions of it) provides a buffer on the negative effects of difficult live events. We analyze the case of unemployment, and we show how its effect on happiness is moderated by some (but not all) dimensions of religion. In turn, this provides a window into another way religion matters to people - especially when seeking happiness in hard times. 


\section{Notes}

1. There is often confusion of the nuances of happiness, life-satisfaction, or subjective wellbeing. Or, debate as to whether there are any differences at all. Here we assume self-reported survey measures of happiness are adequate (also see Crooker and Near 1998). In our analyses we are limited to a single self-reported measure of happiness.

2. Another framing for this moderating effect could come from the "Stress Process Model", a conceptual framework that attempts to predict mental health outcomes by interrogating the relationship(s) between life events, chronic life strains, self-concepts, coping, and social support (Pearlin et al. 1981). Under this model, negative life events paired with chronic problems can lead to secondary stressors, such as unhappiness and depression, which can be moderated through resources like coping and social support. The problem would be unemployment, the resource for coping would be religion, and the outcome would be happiness.

3. The data are publicly available (http://gss.norc.org). Analysis code is available on the corresponding author's website.

4. In the GSS, this question is asked of all respondents, regardless of their answers to other religion questions. For the most part, we expect less religious people to disagree more with this statement because they have fewer beliefs to "carry over." We visualize this in Appendix Figure 3.

5. Logistic regression models on the binary religion variables (attend monthly, pray daily, believe god exists, belief in life after death) also found null effects (Appendix Table A16).

6. Non-religious forms of community might also buffer the negative effects of unemployment on happiness. Examining potential non-religious moderators is beyond the scope of this paper, but future work could compare religious and non-religious moderators.

7. Someone can only do this if they have religious beliefs to apply. This suggests an interaction between beliefs and one's effort to apply them. Additional fixed effects models with a triple interaction term between unemployment, religious beliefs, and applying those beliefs were not conclusive, but also likely statistically underpowered. 


\section{References}

Alderson, Arthur S. and Tally Katz-Gerro. 2016. "Compared to Whom? Inequality, Social Comparison, and Happiness in the United States." Social Forces 95(1):25-54.

Allison, Paul D. 2009. Fixed Effects Regression Models. SAGE Publications.

Andrews, Frank M. and John P. Robinson. 1991. "Measures of Subjective Well-Being." Pp. 61114 in Measures of personality and social psychological attitudes, Measures of social psychological attitudes, Vol. 1. San Diego, CA, US: Academic Press.

Argyle, Michael. 2013. The Psychology of Happiness. Routledge.

Bradley, E. 1995. "Religious Involvement and Social Resources: Evidence from the Data Set 'Americans", Changing Lives".'” Journal for the Scientific Study of Religion 34(2):25967.

Bradshaw, Matt and Christopher G. Ellison. 2010. "Financial Hardship and Psychological Distress: Exploring the Buffering Effects of Religion.” Social Science \& Medicine 71(1):196-204.

Brady, David, Ryan M. Finnigan, and Sabine Hübgen. 2017. "Rethinking the Risks of Poverty: A Framework for Analyzing Prevalences and Penalties." American Journal of Sociology 123(3):740-86.

Clark, Andrew E., Ed Diener, Yannis Georgellis, and Richard E. Lucas. 2008. "Lags And Leads in Life Satisfaction: A Test of the Baseline Hypothesis." The Economic Journal 118(529):F222-43.

Clark, Andrew E. and Andrew J. Oswald. 1994. "Unhappiness and Unemployment." The Economic Journal 104(424):648-59.

Clark, Andrew and Orsolya Lelkes. 2005. "Deliver Us from Evil: Religion as Insurance.” Papers on Economics of Religion Working Paper 06/03.

Crooker, Karen J. and Janet P. Near. 1998. "Happiness and Satisfaction: Measures of Affect and Cognition?” Social Indicators Research 44(2):195-224.

Darity, William and Arthur H. Goldsmith. 1996. "Social Psychology, Unemployment and Macroeconomics.” Journal of Economic Perspectives 10(1):121-140.

Di Tella, Rafael, Robert J. MacCulloch, and Andrew J. Oswald. 2001. "Preferences over Inflation and Unemployment: Evidence from Surveys of Happiness." American Economic Review 91(1):335-341.

Diener, E. 2000. "Subjective Well-Being. The Science of Happiness and a Proposal for a National Index." The American Psychologist 55(1):34-43. 
Diener, Ed, Louis Tay, and David G. Myers. 2011. "The Religion Paradox: If Religion Makes People Happy, Why Are so Many Dropping Out?” Journal of Personality and Social Psychology 101(6):1278-90.

Easterlin, Richard A. 2003. "Explaining Happiness." Proceedings of the National Academy of Sciences 100(19):11176-83.

Eichhorn, Jan. 2012. "Happiness for Believers? Contextualizing the Effects of Religiosity on Life-Satisfaction.” European Sociological Review 28(5):583-93.

Ellison, Christopher G. 1991. "Religious Involvement and Subjective Well-Being." Journal of Health and Social Behavior 32(1):80-99.

Ellison, Christopher G., Amy M. Burdette, and Terrence D. Hill. 2009. "Blessed Assurance: Religion, Anxiety, and Tranquility among US Adults." Social Science Research 38(3):656-67.

Ellison, Christopher G. and Linda K. George. 1994. "Religious Involvement, Social Ties, and Social Support in a Southeastern Community." Journal for the Scientific Study of Religion 33(1):46-61.

Ellison, Christopher, David Gay, and Thomas Glass. 1989. "Does Religious Commitment Contribute to Individual Life Satisfaction?” Social Forces 68(1):100.

Emmons, Robert, Chi Cheung, and Keivan Tehrani. 1998. "Assessing Spirituality Through Personal Goals: Implications for Research on Religion and Subjective Well-Being." Social Indicators Research 45(1):391-422.

Exline, Julie J., Kenneth I. Pargament, Joshua B. Grubbs, and Ann Marie Yali. 2014. "The Religious and Spiritual Struggles Scale: Development and Initial Validation." Psychology of Religion and Spirituality 6(3):208.

Farias, Miguel, Anna-Kaisa Newheiser, Guy Kahane, and Zoe de Toledo. 2013. "Scientific Faith: Belief in Science Increases in the Face of Stress and Existential Anxiety." Journal of Experimental Social Psychology 49(6):1210-1213.

Ferriss, Abbott L. 2002. "Religion and the Quality of Life.” Journal of Happiness Studies 3(3):199-215.

Fischer, Claude S. 2008. "What Wealth-Happiness Paradox? A Short Note on the American Case." Journal of Happiness Studies 9(2):219-26.

Flannelly, Kevin J., Harold G. Koenig, Christopher G. Ellison, Kathleen Galek, and Neal Krause. 2006. "Belief in Life After Death and Mental Health: Findings from a National Survey." The Journal of Nervous and Mental Disease 194(7):524-29.

Frey, Bruno S. and Alois Stutzer. 2002. "What Can Economists Learn from Happiness Research?" Journal of Economic Literature 40(2):402-35. 
Goldsmith, Arthur H., Jonathan R. Veum, and William Darity. 1996. "The Psychological Impact of Unemployment and Joblessness." Journal of Socio-Economics 25(3):333-358.

Granovetter, Mark S. 1973. "The Strength of Weak Ties.” American Journal of Sociology 78(6):1360-80.

Greeley, Andrew M. and Michael Hout. 2008. The Truth about Conservative Christians: What They Think and What They Believe. University of Chicago Press.

Green, Morgan and Marta Elliott. 2010. "Religion, Health, and Psychological Well-Being." Journal of Religion and Health 49(2):149-63.

Greene, Kenneth V. and Bong Joon Yoon. 2004. "Religiosity, Economics and Life Satisfaction." Review of Social Economy 62(2):245-61.

Hackney, Charles H. and Glenn S. Sanders. 2003. "Religiosity and Mental Health: A MetaAnalysis of Recent Studies.” Journal for the Scientific Study of Religion 42(1):43-56.

Hahn, Elisabeth, Jule Specht, Juliana Gottschling, and Frank M. Spinath. 2015. "Coping With Unemployment: The Impact of Unemployment Duration and Personality on Trajectories of Life Satisfaction.” European Journal of Personality 29(6):635-646.

Henrich, J., S. J. Heine, and A. Norenzayan. 2010. "The Weirdest People in the World?" Behavioral And Brain Sciences 33(2-3):61-135.

Hill, Peter C. and Kenneth I. Pargament. 2008. "Advances in the Conceptualization and Measurement of Religion and Spirituality: Implications for Physical and Mental Health Research."

Hiswåls, Anne-Sofie, Anneli Marttila, Emelie Mälstam, and Gloria Macassa. 2017. "Experiences of Unemployment and Well-Being after Job Loss during Economic Recession: Results of a Qualitative Study in East Central Sweden.” Journal of Public Health Research 6(3).

Hout, Michael. 2017. "Models for Three-Wave Panel Data: Examples Using the General Social Survey Panels." Sociological Methods \& Research 46(1):41-43.

Hout, Michael and Andrew M. Greeley. 2012. "Religion and Happiness." Social Trends in American Life 288-314.

Hout, Michael and Orestes P. Hastings. 2014. "Recession, Religion, and Happiness, 20062010." Religion and Inequality in America: Research and Theory on Religion's Role in Stratification 311.

Hout, Michael and Orestes P. Hastings. 2016. "Reliability of the Core Items in the General Social Survey: Estimates from the Three-Wave Panels, 2006-2014.” Sociological Science 3:971-1002. 
Inglehart, Ronald F. 2010. "Faith and Freedom: Traditional and Modern Ways to Happiness." Pp. 351-97 in International differences in well-being. New York, NY, US: Oxford University Press.

Jung, Jong Hyun. 2014. "Religious Attendance, Stress, and Happiness in South Korea: Do Gender and Religious Affiliation Matter?” Social Indicators Research 118(3):1125-45.

Kahneman, Daniel and Angus Deaton. 2010. "High Income Improves Evaluation of Life but Not Emotional Well-Being." Proceedings of the National Academy of Sciences 107(38):16489-93.

Kearney, Melissa S. and Phillip B. Levine. 2016. "Income Inequality, Social Mobility, and the Decision to Drop Out of High School.” Brookings Papers on Economic Activity 333-80.

King, Morton B. and Richard A. Hunt. 1975. "Measuring the Religious Variable: National Replication." Journal for the Scientific Study of Religion 14(1):13-22.

Knabe, Andreas and Steffen Rätzel. 2011. "Scarring or Scaring? The Psychological Impact of Past Unemployment and Future Unemployment Risk.” Economica 78(310):283-93.

Koenig, Harold G. and Arndt Büssing. 2010. "The Duke University Religion Index (DUREL): A Five-Item Measure for Use in Epidemological Studies.” Religions 1(1):78-85.

Korpi, Tomas. 1997. "Is Well-Being Related to Employment Status? Unemployment, Labor Market Policies and Subjective Well-Being among Swedish Youth." Labour Economics (4):125-47.

Krause, Neal. 2002. "Church-Based Social Support and Health in Old Age: Exploring Variations by Race." The Journals of Gerontology: Series B 57(6):S332-47.

Krause, Neal. 2005. "God-Mediated Control and Psychological Well-Being in Late Life." Research on Aging 27(2):136-64.

Krause, Neal. 2008. "The Social Foundation of Religious Meaning in Life." Research on Aging 30(4):395-427.

Krause, Neal and Keith M. Wulff. 2005. "Friendship Ties in the Church and Depressive Symptoms: Exploring Variations by Age." Review of Religious Research 46(4):325-340.

Kroll, Christian. 2014. "Towards a Sociology of Happiness: The Case of an Age Perspective on the Social Context of Well-Being." Sociological Research Online 19(2):1-18.

Krueger, Alan B. and David A. Schkade. 2008. "The Reliability of Subjective Well-Being Measures.” Journal of Public Economics 92(8-9):1833-45.

Krueger, Alan, Daniel Kahneman, Claude Fischler, David Schkade, Norbert Schwarz, and Arthur Stone. 2009. "Time Use and Subjective Well-Being in France and the U.S." Social Indicators Research 93(1):7-18. 
Latsou, Dimitra and Mary Geitona. 2018. "The Effects of Unemployment and Economic Distress on Depression Symptoms.” Materia Socio-Medica 30(3):180-84.

Lechner, Clemens M. and Thomas Leopold. 2015. "Religious Attendance Buffers the Impact of Unemployment on Life Satisfaction: Longitudinal Evidence from Germany." Journal for the Scientific Study of Religion 54(1):166-174.

Lechner, Clemens M., Martin J. Tomasik, Rainer K. Silbereisen, and Jacek Wasilewski. 2013. "Exploring the Stress-Buffering Effects of Religiousness in Relation to Social and Economic Change: Evidence From Poland." Psychology of Religion and Spirituality $5(3): 145-156$.

Lewis, Christopher Alan, John Maltby, and Liz Day. 2005. "Religious Orientation, Religious Coping and Happiness among UK Adults." Personality and Individual Differences 38(5):1193-1202.

Lim, Chaeyoon and Carol Ann MacGregor. 2012. "Religion and Volunteering in Context Disentangling the Contextual Effects of Religion on Voluntary Behavior." American Sociological Review 77(5):747-79.

Lim, Chaeyoon and Robert D. Putnam. 2010. "Religion, Social Networks, and Life Satisfaction." American Sociological Review 75(6):914-33.

Lun, Vivian Miu-Chi and Michael Harris Bond. 2013. "Examining the Relation of Religion and Spirituality to Subjective Well-Being Across National Cultures." Psychology of Religion and Spirituality 5(4):304-315.

Maltby, John, Christopher Alan Lewis, and Liza Day. 1999. "Religious Orientation and Psychological Well-Being: The Role of the Frequency of Personal Prayer." British Journal of Health Psychology 4(4):363-78.

McKee-Ryan, Frances M., Zhaoli Song, Connie R. Wanberg, and Angelo J. Kinicki. 2005. "Psychological and Physical Well-Being during Unemployment: A Meta-Analytic Study." Journal of Applied Psychology 90(1):53-76.

Mochon, Daniel, Michael I. Norton, and Dan Ariely. 2011. "Who Benefits from Religion?" Social Indicators Research 101(1):1-15.

Morgan, Stephen L. and Christopher Winship. 2014. Counterfactuals and Causal Inference. Cambridge University Press.

Mouw, Ted. 2003. “Social Capital and Finding a Job: Do Contacts Matter?” American Sociological Review 68(6):868-98.

Myers, David G. 2008. "Religion and Human Flourishing." Pp. 323-43 in The science of subjective well-being. New York, NY, US: Guilford Press. 
Oesch, Daniel and Oliver Lipps. 2012. "Does Unemployment Hurt Less If There Is More of It around? A Panel Analysis of Life Satisfaction in Germany and Switzerland.” European Sociological Review 29(5):955-967.

Okulicz-Kozaryn, Adam. 2010. "Religiosity and Life Satisfaction across Nations.” Mental Health, Religion \& Culture 13(2):155-69.

Pargament, Kenneth I. 1997. The Psychology of Religion and Coping: Theory, Research, Practice. New York: Guilford Press.

Pargament, Kenneth I. 2010. "Religion and Coping: The Current State of Knowledge." The Oxford Handbook of Stress, Health, and Coping.

Pargament, Kenneth I., Bruce W. Smith, Harold G. Koenig, and Lisa Perez. 1998. "Patterns of Positive and Negative Religious Coping with Major Life Stressors." Journal for the Scientific Study of Religion 37(4):710-24.

Pearlin, Leonard I., Elizabeth G. Menaghan, Morton A. Lieberman, and Joseph T. Mullan. 1981. "The Stress Process." Journal of Health and Social Behavior 22(4):337-56.

Presser, Stanley and Mark Chaves. 2007. “Is Religious Service Attendance Declining?” Journal for the Scientific Study of Religion 46(3):417-23.

Regnerus, Mark D. and Christian Smith. 2005. "Selection Effects in Studies of Religious Influence." Review of Religious Research 47(1):23-50.

Roof, Wade Clark and William McKinney. 1987. American Mainline Religion: Its Changing Shape and Future. Rutgers University Press.

Schieman, Scott, Tetyana Pudrovska, Leonard I. Pearlin, and Christopher G. Ellison. 2006. "The Sense of Divine Control and Psychological Distress: Variations Across Race and Socioeconomic Status.” Journal for the Scientific Study of Religion 45(4):529-49.

Schnabel, Landon and Sean Bock. 2017. "The Persistent and Exceptional Intensity of American Religion: A Response to Recent Research.” Sociological Science 4:686-700.

Shams, M. and P. R. Jackson. 1993. "Religiosity as a Predictor of Well-Being and Moderator of the Psychological Impact of Unemployment." The British Journal of Medical Psychology $66(\mathrm{Pt} 4): 341-52$.

Smith, Richard H., Ed Diener, and Douglas H. Wedell. 1989. "Intrapersonal and Social Comparison Determinants of Happiness: A Range-Frequency Analysis.” Journal of Personality and Social Psychology 56(3):317-325.

Smith, Timothy, Michael McCullough, and Justin Poll. 2003. "Religiousness and Depression: Evidence for a Main Effect and the Moderating Influence of Stressful Life Events." Psychological Bulletin 129(4):614-36. 
Smith, Tom W. 1979. "Happiness: Time Trends, Seasonal Variations, Intersurvey Differences, and Other Mysteries.” Social Psychology Quarterly 42(1):18-30.

Strawbridge, W. J., S. J. Shema, R. D. Cohen, R. E. Roberts, and G. A. Kaplan. 1998.

"Religiosity Buffers Effects of Some Stressors on Depression but Exacerbates Others." The Journals of Gerontology. Series B, Psychological Sciences and Social Sciences 53(3):S118-126.

Vaisey, Stephen and Andrew Miles. 2017. "What You Can—and Can't—Do With Three-Wave Panel Data." Sociological Methods \& Research 46(1):44-67.

VanderWeele, Tyler J. 2017a. "On the Promotion of Human Flourishing." Proceedings of the National Academy of Sciences 114(31):8148-56.

VanderWeele, Tyler J. 2017b. "Religious Communities and Human Flourishing." Current Directions in Psychological Science 26(5):476-81. 